The internal resistance of non-polluting, high-temperature solid oxide fuel cells operated on natural or coal gas must be minimized for efficient and cost effective electricity generation.

\title{
Fuel Cells
}

Fuel cells are electric batteries capable of converting atmospheric hydrogen and oxygen (and in some cases natural gas and coal gas) into electricity, heat and water without combustion. They comprise an anode and a cathode separated by an electrolyte, and the main types are usually named after the electrolyte. Table 1 specifies the principle parameters while Fig. 1 shows the basic structure of a fuel cell and the electrochemical reactions taking place in the various types.

As an individual fuel cell only produces about $0.5-1.0 \mathrm{~V}$ it is necessary to stack cells. Several geometries are possible apart from the planar configuration illustrated in Fig. 2. For instance, tubular arrangements that are more easily produced, but for which the electricity losses in the cell stack are larger as the current path is longer. The electrodes must be good electronic conductors as well as being porous in order for the fuel gas to penetrate and react. The porous structure should be designed to provide the largest possible contact area between the ion-conducting electrolyte, the electron conducting electrode and the gas phase.

Processes in a fuel cell involve the direct conversion of chemical energy to electricity without using thermal energy in an intermediate step. Consequently, fuel cells are not subject to the thermodynamic limitations found in a Carnot engine (piston engine or turbine) and it is therefore in principle possible to achieve a high efficiency. Furthermore, the temperature in a fuel cell is low compared to that of a flame so nitrous oxide is not evolved, which is why fuel cells are less polluting. Other advantages include a low noise level (the only rotating components are found in pumps) and a modular structure, implying that both the price per $\mathrm{kW}$ installed and the efficiency are roughly independent of the size of the unit.

\section{Early History}

In 1839, the English physicist Sir William Grove made the remarkable discovery that when water was decomposed during the

Mogens Mogensen manages Danish and EC solid oxide fuel cell projects. He received a masters in chemical engineering from the Technical University of Denmark and a Ph.D. in corrosion science from the university in 1976. After holding various positions in the university, he joined the Hellesen Research Laboratory before moving in 1980 to the Materials Department, Risø National Laboratory, P.O. Box 49, DK-4000 Roskilde.

Niels Christiansen heads the Advanced Ceramics Group at Haldor Topsøe A/S, Nymøllevej 55, DK-2800 Lyngby. He received a masters in chemistry from the Technical University of Denmark and has worked on advanced materials at the Danish Technological Institute.

\section{FAMILIAR PRINCIPLES FOR ELECTRICITY GENERATION}

\author{
M. Mogensen ${ }^{1}$, N. Christiansen ${ }^{2}$ \\ ${ }^{1}$ Riso National Laboratory, Denmark \\ 2 Haldor Topsøe A/S, Denmark
}

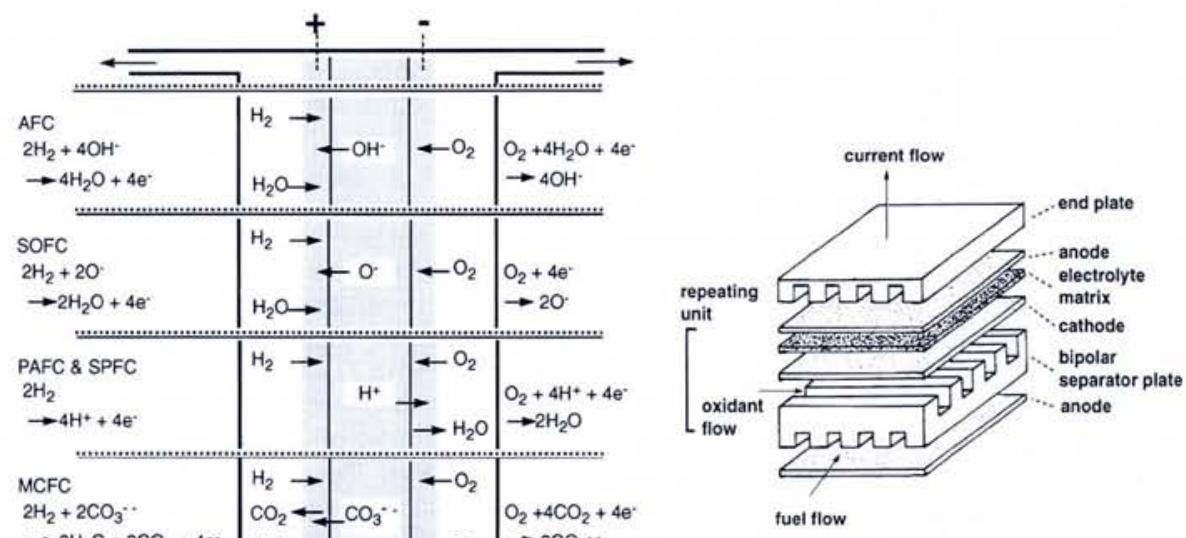

Fig. 2 - An expanded view of the basic fuel cell structure with the repeating unit of the fuel cell stack. cathode electrolyte

Fig. 1-An illustration of the basic structure of a fuel cell: fuel gases are fed at the anode and cathode which are separated by an electrolyte. The electrochemical reactions arising in the five principal types of fuel cells are indicated.

electrolysis of dilute sulphuric acid between platinum electrodes, the process could be reversed on switching off the power source because the small amounts of hydrogen and oxygen remaining on the electrodes were able to produce a weak electric current. Grove achieved academic fame for his discovery but many years were to pass before anyone started to develop fuel cells for electricity production. Research had its first major advance when Mond and Langer introduced the porous electrode in the 1890 's. In 1895, W.W. Jacques developed a large system capable of producing a reasonable amount of electric power. He connected 100 fuel cells, each consisting of an iron cathode and a coal anode placed in molten potassium hydroxide at $450^{\circ} \mathrm{C}$ with air blown around the iron electrode. Fue was provided by the coal which oxidised to carbonate. The output amounted to $1.5 \mathrm{~kW}$, sufficient to keep 25 ordinary electric bulbs alight, but only for a short time as the precipitation of carbonate around the coal anodes blocked the cells.

A important era was introduced when F.T. Bacon started in 1933 the development of alkaline fuel cells based on an aqueous solution of potassium hydroxide at $200^{\circ} \mathrm{C}$, where hydrogen and oxygen at 45 atmospheres were brought in contact with electrodes of porous nickel. But is was not until 1959 that a demonstration unit was ready.

\section{Low-Temperature Fuel Cells}

The main reason why the alkaline fuel cell has not yet experienced commercial success is because it does not tolerate carbon dioxide which reacts with the hydroxide to form a carbonate, thus destroying the electrolyte. The $\mathrm{CO}_{2}$ in both the hydrogen and the oxygen fuel gases must be reduced to a few ppm - a fairly expensive process. Recognition of this led in the 1960's and 1970's to the development of $\mathrm{CO}_{2}$-tolerant cells. One of these (the solid proton conductor fuel cell - SPFC) employs an expensive polymeric proton conductor ion-exchange membrane as the electrolyte. The anode is poisoned by $\mathrm{CO}$ at the relatively low operat- 
ing temperature so hydrogen made by reforming hydrocarbons cannot be employed without a purification stage, which increases costs. Consequently, SPFC's have not yet been put to use except in the area of space travel.

The other type of $\mathrm{CO}_{2}$-tolerant fuel cell is the phosphoric acid fuel cell (PAFC). In about 1970, a group at United Technology Corporation, Connecticut, USA, called attention to the fact that phosphoric acid can be exploited as a $\mathrm{CO}_{2}$-rejecting electrolyte at $150-200^{\circ} \mathrm{C}$. A large-scale development programme resulted in a demonstration unit of $4.5 \mathrm{MW}$ and a $11 \mathrm{MW}$ unit is presently being tested in Japan. Although the PAFC's generate electricity at prices similar to those for conventional plant, it is anticipated that their market share will be limited.

The low-temperature fuel cells have a generic problem in that they cannot convert hydrocarbons or carbon monoxides directly; it is necessary to fuel them with hydrogen which usually has to be produced from fossil fuel. Furthermore, the hydrogen must not contain $\mathrm{CO}$, except in the case of PAFC's which tolerate $\mathrm{CO}$ concentrations approaching $100 \mathrm{ppm}$. Reforming fossil fuel into hydrogen involves a considerable energy loss. People working with power stations often calculate the efficiency by taking the Higher Heating Values (HHV) of the primary fuel as the starting point. The HHV is numerically equal to the change in the standard enthalpy $\Delta H^{\circ}{ }_{298}$ at $298 \mathrm{~K}$ and one atmosphere, but with an opposite sign. The overall efficiency of low-temperature cells is only about $40 \%$ of the HHV for methane. As the main argument in favour of fuel cells should be a higher efficiency, this argument is lost as gas turbines used for electricity generation have today efficiencies of about $40 \%$.

\section{High-Temperature Fuel Cells}

High-temperature fuel cells based on molten carbonate (MCFC) and solid oxide (SOFC) electrolytes can convert natural gas as well as $\mathrm{CO}$ either by internal reforming of by direct electrochemical reaction. They are therefore much more efficient than low-temperature cells. Both types were invented by E. Bauer, the Swiss chemist, in the 1920's and 1930's, but it was not until the 1980's

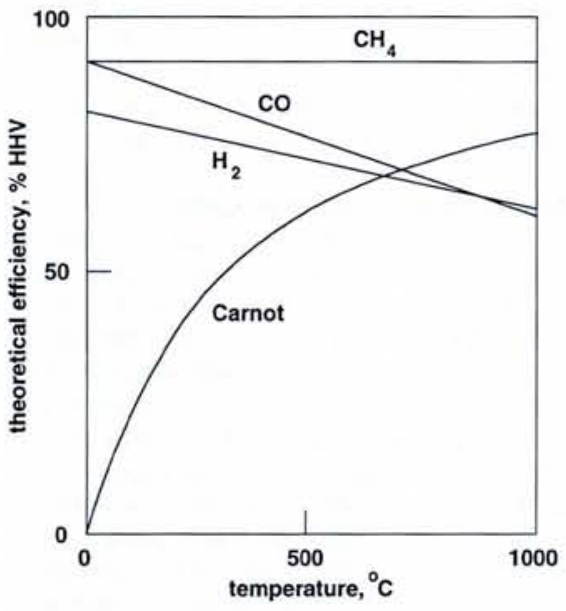

Fig. 3-Comparison between the theoretical efficiency of fuel cells for $\mathrm{CH}_{4}, \mathrm{CO}$ and $\mathrm{H}_{2}$ fuel gases and the Carnot efficiency.

Table 1 - Characteristics of the most important types of fuel cells.

\begin{tabular}{|c|c|c|c|c|c|}
\hline & $\begin{array}{c}\text { Alkaline } \\
\text { AFC }\end{array}$ & $\begin{array}{l}\text { Solid proton } \\
\text { conductor } \\
\text { SPFC }\end{array}$ & $\begin{array}{c}\text { Phosphoric } \\
\text { acid } \\
\text { PAFC }\end{array}$ & $\begin{array}{c}\text { Molten } \\
\text { carbonate } \\
\text { MCFC }\end{array}$ & $\begin{array}{l}\text { Solid } \\
\text { oxide } \\
\text { SOFC }\end{array}$ \\
\hline Electrolyte & aq. $\mathrm{HOH}$ & $\begin{array}{l}\text { polymer } \\
\mathrm{H}^{+} \text {cond. }\end{array}$ & $\mathrm{H}_{3} \mathrm{PO}_{4}$ & $\mathrm{KLiCO}_{3}$ & $\mathrm{ZrO}_{2}+\mathrm{Y}_{2} \mathrm{O}_{3}$ \\
\hline Anode & porous $\mathrm{Ni}$ & $\begin{array}{l}\text { graphite } \\
+\mathrm{Pt}\end{array}$ & $\begin{array}{l}\text { graphite } \\
+\mathrm{Pt}\end{array}$ & porous $\mathrm{Ni}$ & $\mathrm{Ni}+\mathrm{Zr}(\mathrm{Y}) \mathrm{O}_{2}$ \\
\hline Cathode & $"$ & $"$ & 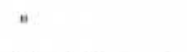 & $\mathrm{NiO}_{2}+\mathrm{Li}_{2} \mathrm{O}$ & $\mathrm{LaMnO}_{3}+\mathrm{Sr}$ \\
\hline Fuel & pure $\mathrm{H}_{2}$ & pure $\mathrm{H}_{2}$ & $\mathrm{H}_{2}$ (CO-free) & $\begin{array}{l}\mathrm{H}_{2}+\mathrm{CO} \\
+ \text { nat. gas }\end{array}$ & $\begin{array}{l}\mathrm{H}_{2}+\mathrm{CO} \\
+ \text { nat. gas }\end{array}$ \\
\hline Opern. temp. ${ }^{\circ} \mathrm{C}$ & 100 & 100 & 200 & 650 & 1000 \\
\hline Efficiency, \% & $\approx 40$ & $\approx 40$ & $=40$ & $\approx 60$ & $\approx 60$ \\
\hline Price, $\$$ US/kW & $\approx 20$ & $=700$ & $=200$ & $=80$ & $\approx 150$ \\
\hline
\end{tabular}

that their development was accelerated. Demonstration units of $25 \mathrm{~kW}$ of both types have been built.

Carbon dioxide must be added to the cathode together with air in MCFC's since it is the $\mathrm{CO}_{3}{ }^{-}$ions which carry charge. Carbon dioxide is generated at the anode if methane is converted in the cell so it is necessary to extract the $\mathrm{CO}_{2}$ from the anode exhaust and recycle it to the cathode. The most important problem facing MCFC's today is the extremely corrosive nature of the $\mathrm{O}_{2}$ - and $\mathrm{CO}_{2}$-saturated molten salt, which limits the lifetime of the cell.

SOFC's made entirely from solid oxides seem to have the greatest potential and both high efficiency $(>50 \%)$ and a long lifetime (> 50000 hours) have been demonstrated. The main challenge is to develop a sufficiently inexpensive and reproducible fabrication technology for the thin ceramic layers which constitute the electrodes and the electrolyte. While this will take at least 10 years, the prospects are so good that considerable effort is being made worldwide to realize the potential of SOFC's.

\section{Efficiency}

The maximum amount of work that can be obtained from a chemical reaction is equal to the Gibb's free-energy change $\Delta \mathrm{G}$ given by the well-known formula $\Delta G=\Delta H-T \Delta S$ for an enthalpy $\Delta H$ and an entropy $\Delta S$. The theoretical efficiency $\eta_{t}$ which can be achieved by a fuel cell working at a temperature $T$ is therefore

$$
\eta_{\mathrm{t}}=\frac{\Delta G}{\Delta H^{\circ}{ }_{298}}=\frac{\Delta H-T \Delta S}{\Delta H^{\circ}{ }_{298}}
$$

where $\Delta G, \Delta H$ and $\Delta S$ refer to the operating conditions. For Carnot engines,

$$
\eta_{\mathrm{t}}=\frac{T-T_{\mathrm{o}}}{T}
$$

where $T_{0}$ is the temperature of the exit gas.

\section{Entropy effects}

Proponents of fuel cells often claim that the comparison of Eqs. 1 and 2 demonstrates that fuel cells can achieve higher efficiencies than Carnot engines. However, this is a very simple arguement. Fig. $3 \mathrm{com}$ paring the theoretical efficiency of fuel cells for three different fuel gases $\left(\mathrm{H}_{2}, \mathrm{CO}\right.$ and $\mathrm{CH}_{4}$ ) with the Carnot curve shows that only $\mathrm{CH}_{4}$ gives a higher efficiency over the entire temperature range between 25 and 1000 ${ }^{\circ} \mathrm{C}$. Differences between the temperature dependences for the three fuel gases stem from changes in the numbers of molecules during reaction. The number for the reactions $2 \mathrm{H}_{2}+\mathrm{O}_{2} \rightarrow 2 \mathrm{H}_{2} \mathrm{O}$ and $2 \mathrm{CO}+\mathrm{O}_{2} \rightarrow$ $2 \mathrm{CO}_{2}$ is changed from 3 to 2 , resulting in a loss of entropy, whereas there is no change for the reaction $\mathrm{CH}_{4}+2 \mathrm{O}_{2} \rightarrow \mathrm{CO}_{2}+2 \mathrm{H}_{2} \mathrm{O}$.

For a fuel cell running on hydrogen, it is seen from Fig. 3 that low-temperature operation is the most advantageous. However, this is only true in practice in special situations where a direct source of hydrogen is available. Hydrogen is normally made from reacting coal, oil or gas with water. A large amount of heat has to be added at a relatively high temperature $\left(600-700^{\circ} \mathrm{C}\right)$ during the reforming process - heat which is recovered in the fuel cell, but at too low a temperature. So low-temperature fuel cells, which can only operate with hydrogen, have efficiencies slightly above $40 \%$ of the HHV for fossil fuels. However, it is possible in practice to increase the efficiency in the case of high-temperature cells by using methane (natural gas), noting of course that the theoretical efficiency will not be reached as there are always losses.

\section{Losses}

Losses developed in the form of heat owing to the internal resistance of the fuel cell stack are determined by the conductivities of the materials used to construct a cells, and by polarization of electrodes caused by a higher than average concentration of reaction products at the electrodes than in the bulk of the electrolyte. The resistance can reduced by choosing a design having a short conducting path in the thin electrodes. This is achieved in the planar design (Fig. 2) where the current need only flow across one-half of the width of the gas channel in the electrodes (typically about $1 \mathrm{~mm}$ ) in order to reach the thicker material connecting cells.

The internal resistance means that the efficiency and power of a fuel cell depend upon the load. The internal resistance $R_{\mathrm{i}}$ (including electrode polarization ) is to a first approximation independent of the current density $I$, so Ohm's law is applicable and the following correlation is found empirically

$$
P=E I-\left.R_{\mathrm{i}}\right|^{2}
$$


for a power density $P$ (in $W / m^{2}$ ) and an open circuit voltage $E$ (also called the electromotive force) of about $1 \mathrm{~V}$ for fuel cells. This equation looks simple, so it should be remembered that $E$ is a function of position as the composition of the fuel gas varies along the cell because of the increasing degree of conversion of the reactant gases. Second, the internal resistance is not exactly constant because the polarization resistance is weakly dependent on the current density.

The cell voltage $U$ is given by:

$$
U=E-R_{i} I
$$

and the voltage efficiency $\eta_{\mathrm{v}}$ is defined as $\eta_{\mathrm{V}}=U / E$.

The electromotive force $E=\Delta G / n F$ where $n$ is the number of electrons per mole and $F$ is Faraday's number. The real efficiency $\eta$ as a fraction of the HHV of the fuel is:

$$
\eta=\eta_{t} \eta_{v} \alpha
$$

where $\alpha$ is the fuel utilisation factor (the ratio of the amount of fuel converted to the amount supplied). Elimination leads to:

$$
\eta=\alpha \cdot n F U / \Delta H^{\circ}{ }_{298}
$$

where the loss for reforming coal into hydrogen is not included.

Figs. $4 a$ and $b$ illustrate what happens to the power density $P$ and cell voltage $U$ for realistic values of $R_{\mathrm{i}}$ for SOFC's. The largest $R_{\mathrm{i}}$ value of $1.8 \Omega \mathrm{cm}^{2}$ is for a stack, the medium value of $0.45 \Omega \mathrm{cm}^{2}$ for a single cell, and the lowest value of $0.09 \Omega \mathrm{cm}^{2}$ is the value calculated from the measured conductivity of the electrolyte and electrode materials assuming in effect that the electrodes are unpolarized (i.e., they have an unlimited electrocatalytic effect). The curves illustrate the importance of the internal resistance for SOFC's as it determines the power density and the cell efficiency.

\section{Applications \\ Spacecraft}

Alkaline cells were developed in the 1960's for the Apollo spacecraft used to explore the moon as they offered useful energy and power densities without the production of waste. The only reaction product is pure water which formed part of the astronauts' water supply. It is interesting to note that the first fuel cell which was employed had a polymeric proton electrolyte developed by General Electric for the Gemini programme but that had not been taken up. This particular type of lightweight design was adopted as space travel requires reduced weight. The "old" alkaline fuel cell of an unique design was chosen for the latter stages of the Apollo programme as its power per unit of weight was higher than for the proton conductor cell. A special space version of the alkaline cell, typically generating $18 \mathrm{~kW}$ for a $120 \mathrm{~kg}$ device, is used today for spacecraft.

Precious metals are the optimum electrode materials for low-temperature fuel cells, and in the case of the spacecraft version, one electrode is made from a mixture of gold and platinum on gold-coated nickel and the other (oxide) electrode from a Pt-Pd alloy coated material. Although NASA has not published the prices of fuel cells for space travel, figures on the order of 1-2
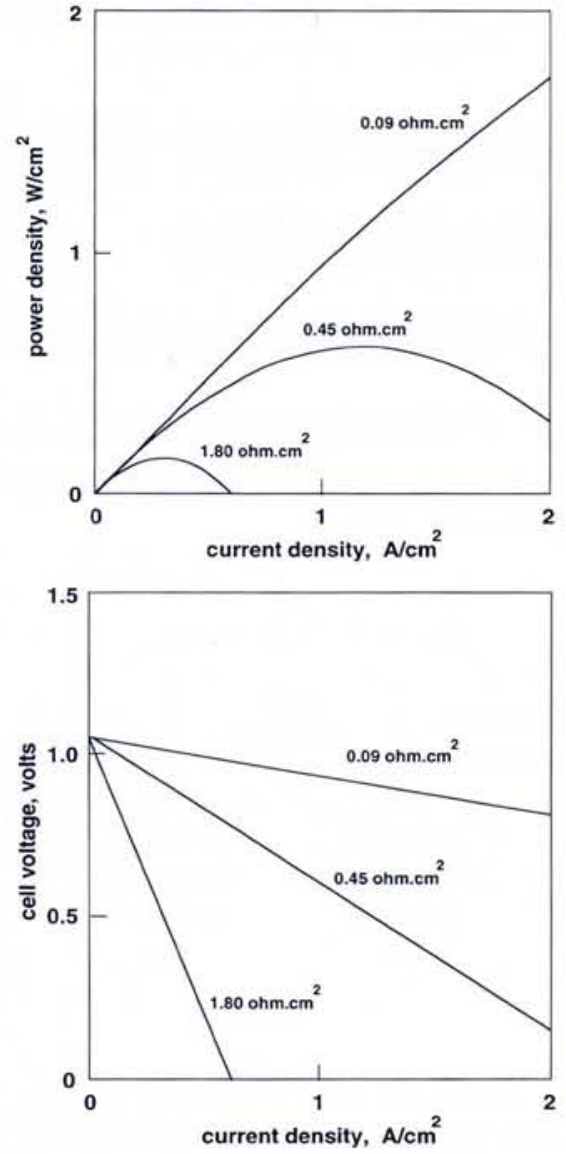

MSUS/kW installed have been mentioned.

Much of what has been learnt about the exploitation of exotic materials for fuel cells used in space can be applied to the development of cheaper types for use on Earth. Special efforts are being made to reduce the prices of alkaline and polymeric proton conductors for fuel cells used in transportrelated applications.

\section{Electric vehicles}

The extent to which fuel cells will be used in electric vehicles depends very much on political decisions regarding the environment. One has to accept that an electric engine costs just as much as a petrol engine, so fuel cells must in fact compete with petrol tanks (i.e., assemblies of bent and welded metal sheet). Electric vehicles with fuel cells will therefore never be able to compete with petrol- and diesel-powered vehicles in the foreseeable future; they have to be treated on different economic terms, which can be justified as fuel cells are nonpolluting.

\section{Power stations}

The situation is totally different for electric power generation. It seems likely that the price of fuel cell plants will decrease in the long run to SUS 1000 per kW installed, which is slightly less than the price of the gas and steam turbine units used today. But it must be emphasized that these prices depend upon the success of research and development programmes.

Three main points should be considered when analysing competivity, namely the construction cost, lifetime and efficiency. The fact that the price of car engines is ge-
Fig. 4 - The power density (upper) and cell voltage (lower) of a solid oxide fuel cell calculated as a function of the current density for three different values of the internal resistance $R_{i}$ of the cell (including polarization resistance). The electrodes are unpolarized along the uppermost curve in each diagram, corresponding to the resistance calculated from the conductivities of the electrolyte and electrode materials.

nerally below SUS 200 per $\mathrm{kW}$ of power illustrates that the construction cost is not decisive. The reason is that the lifetime of a car engine is normally less than four months of continuous operation. Such a short lifetime is unacceptable for a power station, where the requirement is many years.

\section{Everyday applications}

Opportunities offered by fuel cells having the capability to influence everyday life to a considerable extent will eventually be realised. For example, most types of fuel cells are reversible in that they can can be operated as electrolyzers where current is passed into the cell. So fuel cells could be connected to windmills and used to produce oxygen and hydrogen from water when conditions permit: in calm weather, the hydrogen would be fed back into the fuel cell to generate electricity. According to some experts, SOFC's are especially suited for water electrolysis.

Fuel cells do not take up much space and since the oxide fuel cell, for instance, operates with natural gas, it seems reasonable to consider placing fuel cell systems in every house with natural gas at its disposal. A $25 \mathrm{~kW}$ plant sufficient to meet heating and electricity requirements will probably take up no more room than a central heating system does today.

\section{Special applications}

Apart from applications in transport, largescale power generation, and everyday uses there remain a number of unique possibilities. Combined electricity and chemical production is possible (e.g., the selective oxidation of methanol to formaldehyde and the oxidation of ammonia for fertilisers). Research is underway in the area of miniature implanted devices for powering cardiac pacemakers and pumps using blood sugar as the fuel. Finally, there is work in Germany to couple biological systems (e.g., algae production) with fuel cells. In these bio-fuel cells, microorganisms produce convertible substances from $\mathrm{CO}_{2}$ and the sun's energy in a chamber that is connected directly to the anode of a fuel cell.

\section{Conclusion}

Some 1000 MSUS is presently being spent annually on the world-wide research and development of fuel cells. Given this enormous effort, it is certain that electric power generation plants based on high-temperature fuel cells will emerge. Probably operated on natural gas and coal gas, they will be economically competitive with conventional approaches. Nitrous oxide is not produced, sulphur emission should be negligible, and $\mathrm{CO}_{2}$ production per $\mathrm{kWh}$ will be reduced by about 50 percent. 